\title{
Improving Communication English Speaking Skill through Listening Practice for Non-English Majored Students
}

\author{
Ary Iswanto Wibowo ${ }^{1}$, Sayyid Khairunas ${ }^{2}$ \\ ${ }^{1}$ Universitas Bina Sarana Informatika \\ e-mail: ary.anb@bsi.ac.id \\ ${ }^{2}$ Universitas Bina Sarana Informatika \\ e-mail: sayyid.skh@bsi.ac.id,
}

\author{
Cara Sitasi: \\ Wibowo, A. I., \& Khairunnas, S. (2019). Improving Communication English Speaking Skill through Listening \\ Practice for Non-English Majored Students. Wanastra, 11(2), 101-106.
}

\begin{abstract}
The purpose of this study is to investigate the improvement of the student's achievement in speaking by listening practice for Broadcasting and Public Speaking class at Bina Sarana Informatika University. These classes got English subject at even semester. They learnt to focusing on speaking, that's why the researchers help the students to achieve their performance in speaking skill. By using listening practice through audio and video, the researchers hope that they will improve their speaking. The method that has been used by this research was Classroom Action Research (CAR) where the researchers as well as the teachers involved in the class that they are observing. Data were taken by sample of 20 students from each class. Technique for collecting data was descriptive qualitative and quantitative. Technique for analyzing data was used descriptive which describe the finding of the research which used some tables, frequency which was benefit to describe the achievements of the students in speaking from pre-test, cycle 1, and cycle 2. The finding of the research was the students' achievement in speaking were good by using listening practice during a semester. The final achievement from Broadcasting got score 6,24 in average and Public Relation class got score 7,06.
\end{abstract}

\section{Key words: Speaking, Listening Practice, Classroom Action Research}

\section{INTRODUCTION}

One of the four skill of English is speaking. The rest of them are reading, writing, and listening. Listening and Speaking are more complex when it showed up slang and idioms in use. Listening and Speaking, in the opinion of the teachers, are more difficult to practice in classroom conditions. Brown (2000) described "Speaking is an interactive process of constructing meaning that involves producing, receiving and processing information." Students at university level sometime do not feel confident to speak English either inside or outside the classroom. As mentioned Lazaraton (2001) in Romero (2006) said that "in the recent years fluency became the important factor in order to improve speaking ability." Moreover, students should think about how often the communication practice happened inside or outside the classroom. On the contrary, the lack of opportunity to practice speaking and uneven participation make the students could not develop their speaking ability (Ur, 2009; Hosni, 2014). The main problem is that the students are lack of exposure and practice in English continuously. These conditions bring the students to sustain their desire in learning speaking. A challenge for teachers who's their students aren't from English Department, such as Broadcasting and Public
Relation-Majored is inevitably a serious problem. These students are mostly speaking in Bahasa on their daily life and classroom activities. Starting from this issue, the researcher or the writer as known as lecturer has asked to the students the obstacles to speak in English. They convince by the time they listen that they know what the speaker means but they don't know how to respond to the speaker. Therefore, here the writer wants to report a paper to discuss the listening practice to improve the students' speaking skill. Speaking is the primary means for fostering mutual understanding, mutual communication, and using language as the median. The speaking activities in the language class have two-way communication aspect, between the speaker and his hearing on reciprocal basis. Thus, speaking must be first based on: (1) the ability to listen, the ability to speak, and mastery (relative) vocabulary. Here are some steps in the practice of speaking. In early stages, speaking can be said to be similar to a listening exercise. This listening and imitating exercise is a combination of basic exercise for listening skill and speaking skill.

Hosni (2014) stated that speaking is the medium to express meaning or idea which a new language is encountered, understood, practiced, and learnt. On the other hand, "Teaching speaking should organize 
students' thoughts in a meaningful and logic sequence" (Nunan, 2003 as mentioned in Kayi, 2006). This quotation simply said that speaking is the way people communicated with others. The speaking also made people to arrange some words in their thoughts and to come out through mouth in order to be understood by others.

The typical problems of the student in learning speaking according to Richards (2008) are as follows: lack of vocabulary needed to talk about common utterances, lack of communication strategies, cannot participate actively in conversation. Meanwhile, Ur (2009) stated there are some speaking problems that teachers can come across in getting students to talk in the classroom. They are: inhibition, lack of topical knowledge, low or uneven participation and mother-tongue use. Listening plays an important role in second language instruction for several reasons (Rost, 1994). If you can't hear it well, you will find it hard to communicate or perhaps you cannot do listening task for instance. In fact, students often take the wrong way when listening and this lead them to the poor result. It should be noted that the learner's perception of their listening problem and strategies can affect their comprehension both positively and negatively (Wenden in Idrissova and friends, 2015). As stated in Rost (1991), "Listening is an active process requiring participation on the part of the listener". For example, when someone listens to a speaker, he/she processes the information mentally in order to construct an answer. During the listening process the listener is actively engaged. In learning a foreign language, it is important to listen to what is transmitted with a great deal of attention because this helps the listener to reproduce exactly, or almost exactly, what he/she hears. Therefore, listening is not an isolated skill; we listen in order to understand what has been heard. Moreover, the speaker and the listener must be interacting in a social context. If a student understand the speech of a speaker, it gives him/her opportunity to be involved in the process of communication (Idrissova, 2015).

\section{RESEARCH METHODOLOGY}

The study used two cycles of Classroom Action Research (CAR) by McTaggart, 1992. Data were collected through classroom observation, interview with the teachers and students. Yoni (2010:165) states "Classroom action research is how a group of teacher can organize learning condition and learn from their experiences, try to make preparation in their learning, and get the desirable result from their action. Another explanation is derived from Mc Niff (1992:2) described that action research as spiral steps. Each steps had four stages: planning, acting, observing, and reflecting.

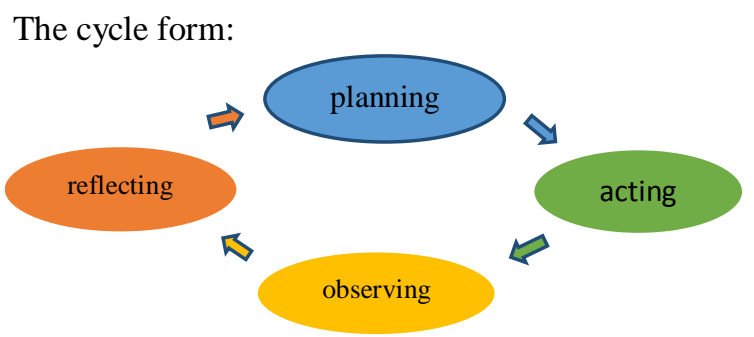

Picture 1. Class Action Research

Below is the explanation of those steps:

1. Planning is related to the activity which is going to be held in the classroom. It is about the lesson plan, material, technique, as well as task to improve the students' achievement; both in form and process.

2. Acting is the action after planning has been managed. It is when the technique, material and tasks are being held or applied.

3. Observing is to see how the activity is running; and to gather the data as the information to be assessed.

4. Reflecting is the stage to reflect how the research has been carried out; from the planning to the observation stage.

Both last two teachers were as well as the researchers of this study. The teachers conducted research at Bina Sarana Informatika University for non-majored English students, which means Public Relation (PR) and Broadcasting Students. The research was created since odd semester of academic year 2018. The teachers handled 40 students each from Public Relation and Broadcasting. One teacher taught Public relation class and another teacher taught Broadcasting Class. This was happened for three months. For another three months, they switched each other with the same material that is listening practice. In assessing the speaking ability, the teachers use Direct Respond Task. As stated in Brown (2003:141), responsive assessment tasks include interaction and test comprehension but at the somewhat limited level of very short conversation, standard greetings and small talk, simple requests and comments, and the like. By listening the audio, students catch the information from the speaker they heard. After that, they conclude and answer some questions. In the first stage of the cycle, the researcher gave the students some material to be 
learnt. By using the method from Mc Niff, the researchers conducted the cycles from planning, acting, observing and reflecting. The researchers planned to prepare some materials for students. The materials were built into listening practice and speaking. On this occasion, audio must be prepared by the researchers. They also should prepared some spoken questions regarding to the audio. In this practice of listening audio, the students can hear three times played audio. At the end of the meeting, the students can only hear the audio once, and they should conclude or discuss the audio that had been played.

\section{FINDING AND RESULT}

After applying listening practice to the students for speaking ability test, the researchers find some significance of the research. Through listening practice, there are improvement from them. The pretest was given by the researchers to the students to compare the significant research of before and after using listening practice technique. Both class, Broadcasting class and Public Relation (PR) Class has 20 students each. They are treated by pre-test and the cycle of the method process. There are some indicators to assess the student's speaking ability, such as pronunciation, structure, vocabulary, smoothness, and understanding. Results from the initial test (Pre-test) are: of 20 Broadcast' students and 20 Public Relations' students who are able to speak by using the correct pronunciation can be seen in the following table:

Table 1. Pre-test score distribution

\begin{tabular}{|c|c|c|c|c|c|c|}
\hline \multirow{2}{*}{$\begin{array}{l}\mathbf{N} \\
\mathbf{o .}\end{array}$} & \multirow{2}{*}{$\begin{array}{c}\text { Span } \\
\text { Scor } \\
\text { es }\end{array}$} & \multirow{2}{*}{$\begin{array}{l}\text { Interpreta } \\
\text { tion }\end{array}$} & \multicolumn{2}{|c|}{ Broadcast } & \multicolumn{2}{|c|}{$\begin{array}{c}\text { Public } \\
\text { Relation }\end{array}$} \\
\hline & & & $\begin{array}{c}\text { Frequen } \\
\text { cies }\end{array}$ & $\%$ & $\begin{array}{c}\text { Frequen } \\
\text { cies }\end{array}$ & $\%$ \\
\hline 1 & $\begin{array}{l}85- \\
100\end{array}$ & Very High & 0 & 0 & 0 & 0 \\
\hline 2 & $\begin{array}{l}75- \\
85\end{array}$ & High & 4 & 20 & 3 & 15 \\
\hline 3 & $\begin{array}{l}65- \\
74\end{array}$ & Enough & 5 & 25 & 12 & 60 \\
\hline 4 & $\begin{array}{l}55- \\
64\end{array}$ & Lack & 11 & 55 & 5 & 25 \\
\hline 5 & $\begin{array}{ll}0 & - \\
54 & \end{array}$ & Low & 0 & 0 & 0 & 0 \\
\hline & & & 20 & $\begin{array}{c}10 \\
0\end{array}$ & 20 & $\begin{array}{c}10 \\
0\end{array}$ \\
\hline
\end{tabular}

Referring to the above result, the majority of the Broadcast's students got score 55 to 64 which means they are lack in speaking skill, and the majority of the PR's students got 65 to 74 which means they are enough in speaking skill.
Based on the observation of the researchers, the initial condition of the class before the researchers use the technique, the students are still difficult to convey the idea, lack the courage to ask questions, lack the ability to formulate their own ideas and the students are not accustomed to complete in conveying opinions to others. When speaking, students still have not noticed the intonation, the proper use of vocabulary, the correct grammar in English and incorporated it into English.

In addition, it can also be seen through some indicators to measure how the ability of the students to speak in English.

Table 2. Pre-test score average

\begin{tabular}{lcc}
\hline \multirow{2}{*}{\multicolumn{1}{c}{ Indicators }} & \multicolumn{2}{c}{ Average Score } \\
\cline { 2 - 3 } & Broadcasting & PR \\
\hline Pronunciation & 4,2 & 6,2 \\
\hline Structure & 4,3 & 5 \\
\hline Vocabulary & 5,3 & 5,7 \\
\hline Smoothness & 4,6 & 6,1 \\
\hline Understanding & 5,6 & 6,8 \\
\hline Average for all indicators & $\mathbf{4 , 8}$ & $\mathbf{5 , 9}$ \\
\hline
\end{tabular}

Both Broadcasting and PR class have score average for themselves. In the pre-test, the Broadcasting students can reach their average score up to 4,6 and Public Relation can reach up to 5,75. The score indicated low for the level of the college students. The highest point from Broadcasting students was vocabulary and the lowest score was pronunciation. Meanwhile, the highest point from PR students was pronunciation and the lowest score was structure. According to the students, they found difficulty to speak in English because they hardly to pronounce the words, to find the proper words, and they are hardly to arrange the sentence into a well structure. Another common habit from the students that they were seldom practicing their English in every day class. Basically, they are understand what the teachers said to them, but they don't know how to respond correctly. Here, the teacher assist them to correct their words and pronunciation to make it better.

\section{Cycle 1}

In the section of the cycle one, researchers observed the students' speaking skill through the indicators that are pronunciation, structure, vocabulary, smoothness, and understanding. The cycle one had been done after the pre-test was given. There was improvement from the students after the Listening practices were held by the researchers. 
Table 3. Average score cycle 1

\begin{tabular}{lcc}
\hline \multirow{2}{*}{\multicolumn{1}{c}{ Indicators }} & \multicolumn{2}{c}{ Average Score } \\
\cline { 2 - 3 } & Broadcasting & PR \\
\hline Pronunciation & 5,5 & 6,8 \\
\hline Structure & 5,3 & 5,8 \\
\hline Vocabulary & 5,8 & 6,5 \\
\hline Smoothness & 5,7 & 6,4 \\
\hline Understanding & 6,2 & 7 \\
\hline Average for all indicators & $\mathbf{5 , 7}$ & $\mathbf{6 , 5}$ \\
\hline
\end{tabular}

From table above, it can be said that Listening practice can increase for some students to acknowledge their skill in speaking communication. Compared with pre-test score, Broadcasting class can reach score up to 5,7 in average and PR class can reach score up to 6,5 in average.

Table 4. Score Distribution for cycle 1(1)

\begin{tabular}{lllcc}
\hline N & Span & Interpret & \multicolumn{2}{c}{ Broadcast } \\
\cline { 4 - 5 } o. & Scores & ation & Frequencies & $\%$ \\
\hline 1 & $85-100$ & Very High & 0 & 0 \\
\hline 2 & $75-85$ & High & 5 & 25 \\
\hline 3 & $65-74$ & Enough & 7 & 35 \\
\hline 4 & $55-64$ & Lack & 8 & 40 \\
\hline 5 & $0-54$ & Low & 0 & 0 \\
\hline \multicolumn{3}{c}{ Total } & 20 & $100 \%$ \\
\hline
\end{tabular}

Table 4. Score Distribution for cycle 1(2)

\begin{tabular}{lllcc}
\hline N & Span & Interpret & \multicolumn{2}{c}{ Public Relation } \\
\cline { 4 - 5 } o. & Scores & ation & Frequencies & \% \\
\hline 1 & $85-100$ & Very High & 0 & 0 \\
\hline 2 & $75-85$ & High & 4 & 20 \\
\hline 3 & $65-74$ & Enough & 13 & 65 \\
\hline 4 & $55-64$ & Lack & 3 & 15 \\
\hline 5 & $0-54$ & Low & 0 & 0 \\
\hline \multicolumn{3}{c}{ Total } & 20 & $100 \%$ \\
\hline
\end{tabular}

In previewing the score distribution cycle, it can be seen that there was increasing in the first cycle of Broadcasting class. Compared with the pre-test, the interpretation score "lack" has decreased from 55\% into $40 \%$ and the interpretation score "enough" has increased up to $35 \%$ from $25 \%$. Meanwhile, the highest score can be achieved as many $25 \%$ high from the previous that was $20 \%$. In the meantime, the PR class also was tended to increase. Compared with pre-test, the interpretation score "lack" has decreased from $25 \%$ to $15 \%$ and the interpretation score "enough" has increased up to $65 \%$ from $60 \%$. In addition, the highest score can be pursuit as many $20 \%$ high from the previous that was $15 \%$.

\section{Cycle 2}

In the second cycle process, the researchers also tend to observe the activities during learning. In this last observation, the researchers found another significant progress from the students. They showed improvement from learning Listening practice. Compared with the cycle one, there was increasing number of students conducting this technique. The scores can be seen as follows:

Table 5. Average score cycle 2

\begin{tabular}{lcc}
\hline \multirow{2}{*}{ Indicators } & \multicolumn{2}{c}{ Average Score } \\
\cline { 2 - 3 } & Broadcasting & PR \\
\hline Pronunciation & 6,1 & 7,4 \\
\hline Structure & 5,8 & 6,3 \\
\hline Vocabulary & 6,5 & 7,2 \\
\hline Smoothness & 6 & 6,9 \\
\hline Understanding & 6,8 & 7,5 \\
\hline $\begin{array}{l}\text { Average for } \\
\text { indicators all }\end{array}$ & $\mathbf{6 , 2 4}$ & $\mathbf{7 , 0 6}$ \\
\hline
\end{tabular}

Based on table above can be concluded that broadcasting class has been increased by their performance on the last cycle as well as the PR class. The scores rose from 5,7 to 6,2 average score and also with PR class raising up from 6,5 to 7,06 . The highest score from the indicators still delivered from "understanding" and the lowest score from "structure". Here the researchers can be concluded that they were understand what people talking about but they difficult to respond correctly. Also with the structure, here they came with fear of language spoken. They would feel afraid to make mistakes. So, they usually speak in Bahasa when they don't know the vocabulary in English.

Table 6. Score distribution for cycle 2(1)

\begin{tabular}{lllcc}
\hline \multirow{2}{*}{ No. } & Span & Interpret & \multicolumn{2}{c}{ Public Relation } \\
\cline { 3 - 5 } & Scores & ation & Frequencies & \% \\
\hline 1 & $85-100$ & Very High & 0 & 0 \\
\hline 2 & $75-85$ & High & 4 & 20 \\
\hline 3 & $65-74$ & Enough & 14 & 70 \\
\hline 4 & $55-64$ & Lack & 2 & 10 \\
\hline 5 & $0-54$ & Low & 0 & 0 \\
\hline \multicolumn{2}{c}{ Total } & 20 & $\begin{array}{c}100 \\
\%\end{array}$ \\
\hline
\end{tabular}

Table 6. Score distribution for cycle 2(2)

\begin{tabular}{lllcc}
\hline \multirow{2}{*}{ No. } & Span & Interpret & \multicolumn{2}{c}{ Public Relation } \\
\cline { 3 - 5 } & Scores & ation & Frequencies & \% \\
\hline 1 & $85-100$ & Very High & 0 & 0 \\
\hline 2 & $75-85$ & High & 4 & 20 \\
\hline 3 & $65-74$ & Enough & 14 & 70 \\
\hline 4 & $55-64$ & Lack & 2 & 10 \\
\hline 5 & $0-54$ & Low & 0 & 0 \\
\hline \multicolumn{3}{r}{ Total } & 20 & $\begin{array}{c}100 \\
\%\end{array}$ \\
\hline
\end{tabular}


Referring table score cycle 2 , it can be seen that increasing number of students who had been observed by researchers showing significant result. Compared with cycle one, in the cycle two the Broadcasting students who got lack skill in speaking was decreased from $40 \%$ to $25 \%$. As well as PR students, they were decreasing from $15 \%$ to $10 \%$. Increasing numbers also have been shown by both Broadcast and PR class to catch their effort. Even there wasn't getting very high score but they have tried to get best score. The Broadcasting class rise the score enough from $35 \%$ up to $45 \%$. While the PR class rise the score enough from $65 \%$ up to $70 \%$. In addition, the high score was achieved by Broadcasting class from $25 \%$ up to $30 \%$. Nevertheless, the PR class was the same number of high score.

\section{RESULTS}

The data that the researchers had been shown indicating there was increasing number in every cycle. It started from pre-test, cycle one, and cycle two. Furthermore, the data can be described as table

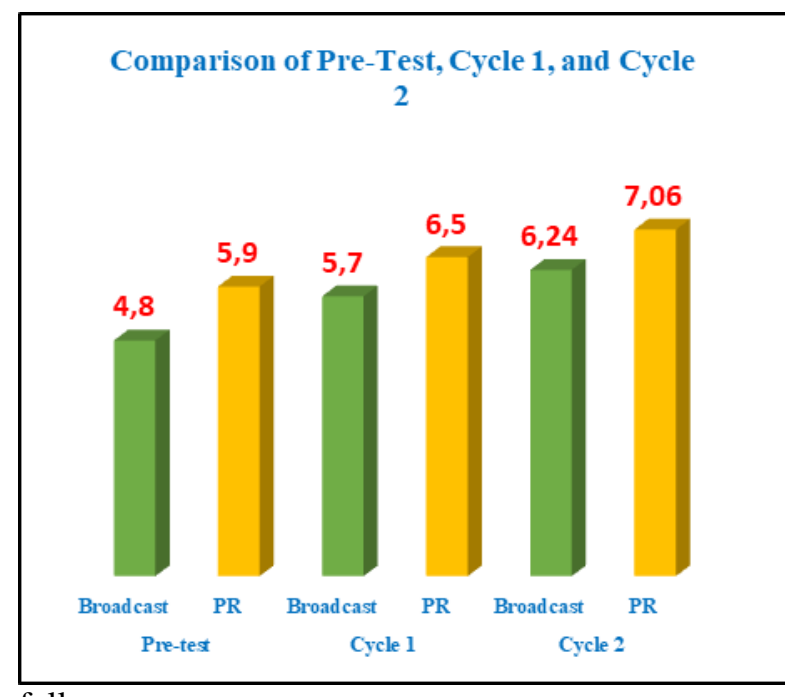

follows:

Picture 2. Comparison Pre-test, Cycle 1, and cycle 2

From the chart, Listening practice technique is quite successful to improve Speaking skill for Broadcasting and Public Speaking's student. It can be seen that there are smoothly significant increasing number from pre-test, cycle one and the cycle two. The six indicators had been assessed the students to improve their skill. The chart represented the indicators of pronunciation, structure, vocabulary, smoothness, and understanding from both Broadcasting and PR class. Listening practice can improve speaking skills in any situation, and help to interact. As for both Broadcasting and PR class, listening practices help to overcome difficulties in speaking. In addition, it is fun and most students think that enjoyment leads to better learning. Students with lack score of English proficiency push the teachers to determine the useful and fruitful activities in improving speaking skill. They changed topics in every meeting so as to make the students bored and knowing the vocabularies. The goal us to consolidate the learning material and practice listening and speaking skill. 10 questions of the previous topics are prepared beforehand by the teachers. The tasks of the students are to listen the questions from audio/video resources and to choose the correct answer. During this listening practice, they use prompts. At the end of this technique, we assessed the student's speaking abilities to express their minds.

As it was mentioned before, students have difficulties in speed of delivery during listening and speaking, face problems with misunderstanding of new words and phrases, have problems in pronunciation of English words, and have difficulties in composing sentences using correct grammatical structure. In order to find solutions to reduce these difficulties, we have them to listen short dialogue repeatedly. In the middle of listening dialogue, we paused for several seconds and then continued till end. After listening to short dialogues, students do exercises for comprehension.

\section{CONCLUSION}

After investigating the research through finding and discussion, the researchers took conclusion that listening practice can improve speaking skill ability. Indeed, the teachers should pay attention to the progress of the students for every meeting. Especially, for the students of non-English majored, they also are categorized as English Foreign Language learners. They need passion and patient to learn English, particularly speaking. What teacher taught in English Class department is different with non-English department. Here, the teachers also demanded to teach attractively, continuously, and 
patiently. In summary, this study is believed to be useful for working in heterogeneous classes. It is hoped that the teachers of English can benefit from this study new ideas and fruitful suggestions to improve listening and speaking skills. Further, studies will carried out in order to get more convincing results.

\section{REFERENCES}

Brown, H. D. (2000). Teaching by Principles: An Interactive Approach to Language Pedagogy, Second Edition. New York: Addison Wesley Longman, Inc.

Brown,H.D. (2003). Language Assessment Principles and Classroom Practices. California: Long Man

Hosni, A. S. (2014). Speaking Difficulties Encountered by Young EFL Learners. International Journal on Studies in English Language and Literature (IJSELL). Volume 2, pp. 22-30

Idrisovva, Mapruza and friends. 2015. Improving listening and speaking skill in mixed level groups (on the material of New English File). Turkey: Procedia Journal (Social and Behavioral Sciences).
Kayi, H. (2006) Teaching Speaking: Activities to Promote Speaking in a Second Language. The Internet TESL Journal Vol. XII No. 11, pp. 1-6

McNiff, J. 1992. Action Research: Principles and Practice, London: Routledge

McTaggart, R. (1992). Action research: Issues in theory and practice. Annual Review of Health Social Science, 3(1), 19-45.

Richard, J.C. (2008, July 10). Teaching Speaking theories and Methodologies. Retrieved from www.professorjackrichards.com

Romero, B.N. (2006). Improving Speaking Skill. Encuentro Vol. 18, pp. $86-90$

Rost, M. 1994. Listening. London: Longman

Syahputri, Diani. 2017. Improving the Students' Ability in Speaking by Using Role Playing Method in the drama Lesson of English Department at 2015-2016 Academic Years. IJLRES-International Journal on Language, Research and Education Studies.

Ur, P. (2009). A Course in Language Teaching Practice and Theory. Cambridge: Cambridge University Press.

Yoni, Acep. 2010. Menyusun Penelitian Tindakan Kelas. Yogyakarta: Familia. 